\title{
PENCIPTAAN NASKAH DRAMA LOLO: TRANSFORMASI KEHIDUPAN PENARI SINTREN PEMALANG
}

\author{
Evi Putrianti \\ Institut Seni Indonesia Yogyakarta
}

\begin{abstract}
Abstrak: Penciptaan naskah drama Lolo merupakan sebuah naskah transformasi kehidupan penari sintren Pemalang. Proses penciptaan naskah drama Lolo dilakukan dengan metode penciptaan menurut Graham Wallas, teori feminisme dilengkapi dengan teori tingkah laku sosial. Tahapan yang dilakukan dalam penciptaan naskah drama Lolo adalah dengan cara melakukan observasi dan wawancara, membaca tinjauan pustaka serta membaca karya-karya terdahulu. Setelah semua data terkumpul, proses selanjutnya adalah mengolahnya menjadi sebuah naskah drama utuh, yang menghasilkan sebuah naskah drama Lolo bertemakan transformasi kehidupan.
\end{abstract}

Kata kunci: Transformasi, Sintren Pemalang, Teori Feminisme, Graham Wallas.

\begin{abstract}
The creation of the Lolo play script creation is based on Pemalang sintren dancers' lives. The creation process is done by Graham Wallas' creation method and feminism combined with behaviorism theory. Steps being done in Lolo's creation are doing observation, interview, literary review, and also by consulting previous reference studies. After all the data has been gathered, the next step proceeds to create the script in unity, resulting in: Lolo play script of life transformation.
\end{abstract}

Key words: Performance, Chinese opera, Chinese legend and myth, acculturation, Semarang, Sanggar Mekar Teratai.

\section{Pendahuluan}

Naskah adalah bentuk rencana tertulis dari cerita drama (Harymawan, 1986).Karya drama termasuk salah satu genre sastra di samping novel, cerpen, dan puisi.Teks drama sebagai gejala kesenian dapat dianggap mencerminkan kenyataan sosial (Sahid, 2008). Maka dari itu naskah drama diharapkan mampu memberikan kritik terhadap kondisi sosial dan politik yang tengah terjadi.Naskah drama sendiri juga diharapkan mampu menjadi bahan penyadaran dan keilmuan bagi pembaca, pelaku dan penikmat teater.

Kehidupan penari Sintren di kecamatan Taman Kabupaten Pemalang Provinsi Jawa Tengah menarik untuk dijadikan sumber bahan penciptaan naskah drama panggung.Kesenian Sintren sebenarnya tidak hanya tersebar didaerah Pemalang, tetapi juga dibeberapa wilayah Jawa Tengah dan Jawa Barat seperti Pekalongan, Batang, Comal, Tegal, Brebes, Ajibarang hingga Cirebon. Sintren sendiri memiliki sebuah latar belakang cerita.

Kesenian sintren di wilayah Jawa Tengah berlatar belakang mitos cinta Raden Sulandono, putra dari Ki Bahurekso dengan Sulasih seorang putri dari Desa Kalisalak, Batang Jawa Tengah. Hubungan asmara tersebut namun tidak mendapat restu dari $\mathrm{Ki}$ Bahurekso, karena tidak direstui oleh sang ayah maka Raden Sulandono memutuskan pergi bertapa dan Sulasih memilih menjadi seorang penari.

Pertemuan diantara keduanya meski tidak berlangsung di dunia nyata, tetapi terus berlangsung melalui alam gaib. Pertemuan 
tersebut diatur oleh Dewi Rantamsari yang memasukkan roh bidadari ke tubuh Sulasih.Raden Sulandono yang tengah bertapa rohnya akan dipanggiluntuk menemui Sulasih.

Sejak saat itu setiap diadakan pertunjukan sintren sang penari pasti akan dimasuki roh bidadari oleh pawangnya, hingga ia mengalamitrance (kesurupan) dan mampu melakukan pertunjukan diluar nalar manusia.

Alunan musik yang rancak dan gerak tari yang seolah-olah tidak digarap atau tersusun, berpusat pada gerak kaki dan tangan dimana gerak-gerak tersebut tidak memiliki nama seperti dalam ragam tari jawa menjadi satu ciri khas dari sintren. Para penari sintren biasa menari dengan tangan terikat, menari di atas sangkar (kurungan ayam) atau menari dengan atraksi lilin saat mengalami trance

(Kesurupan) (Triratnawati, 2012).

Jika ingin menjadi seorang penari sintren maka calon penari sintrendiharuskan masih virgin (perawan), belum pernah berhubungan badan dengan laki-laki dan calon penari sintren diwajibkan untuk berpuasa terlebih dahulu sebelum melakukan pertunjukan. Hal ini dimaksudkan agar ia mampu menahan diri dan suci pikirannya (Duripah, wawancara, 28 Januari 2018). Jika syarat diatas dilanggar, maka roh bidadari tidak akan masuk kedalam diri si penari karena tubuh si penari dianggap sudah kotor, bahkan kasus yang lebih ekstrim saat tidak mentaati syarat yang ada, maka si penari dan para pendukung pertunjukan akan mengalami hal buruk, seperti kesurupan masal, kacaunya pertunjukan, celakanya para pendukung pertunjukan atau hal buruk lainnya (Rusmi, wawancara, 29 Januari 2018).

Kehidupan penari Sintren yang syarat akan mistis dan popularitas dikalangan para penonton khususnya lakilaki, hal ini menimbulkan sebuah pandangan yang beragam dikalangan masyarakat. Hal ini kemudian menimbulkan sikap bagaimana masyarakat pendukungnya menyikapi hal yang terjadi.

Di balik mistisme yang kental dalam dunia Sintren dan anggapan popularitas diantara para lelaki, dunia Sintren sendiri sebenarnya mengandung sisi lain yang kelam. Para penari Sintren biasanya masih berusia dibawah umurketika mulai memasuki dunia Sintren.Seringkali mereka masih duduk dibangku SD atau SMP dengan rata-rata umur 11-15 tahun.Para penari Sintren biasanya juga memiliki latar belakang ekonomi keluarga dibawah ratarata, sehingga akhirnya mereka harus putus sekolah.Beberapa kasus yang terjadi, orang tua para penari Sintren lebih mendukung anaknya untuk menjadi penari daripada melanjutkan pendidikan.Sebuah fakta yang penuh ironi, ditengah kemajuan zaman saat ini.

Kehidupan penari Sintren Pemalang merupakan sebuah kejadian yang sangat menarik, karena mencerminkan kehidupan sosial masyarakat Pemalang yang penuh dengan polemik, kepercayaan terhadap halhal mistis juga keinginan untuk mendapatkan hiburan. Penelitian ini mencoba membedah bagaimana sisi lain kehidupan penari Sintren Pemalang yang tidak hanya tentang gemerlap popularitas, uang sawer dan mistisme. Maka rumusan penciptaan adalah :

1. Bagaimana fakta kehidupan sosial penari sintren menjadi sumber penciptaan naskah drama Lolo?

2. Bagaimana menciptakan naskah drama Lolo sebagai respon ketertindasan kehidupanpenari sintren Pemalang, Jawa Tengah?

Naskah drama yang akan dibuat ini mempunyai beberapa tujuan sebagai berikut: 1. Menuliskan kehidupan sosial penari sintren menjadi naskah drama. 
2. Merespon ketertindasanpenari sintren kedalam wujud naskah drama.

3. Menambah kekayaan naskah drama berdasakan kesenian tradisi di Indonesia.

\section{Landasan Teori}

Naskah drama merupakan karya fiksi, khayalan atau imajinasi.Mochtar Lubis menyatakan, menulis naskah drama diperlukan kepekaan dalam memilih dan menyusun tema atau ide cerita. Ide cerita drama dapat dimulai dari mana saja, biasanya sesuatu yang akhirnya mendorong seorang kreator karena melihat sesuatu, mengalami sesuatu ataupun mendengar sesuatu (Lubis, 1984).

Karya fiksi tidak bisa lahir dari kehampaan dan kekosongan.Karya fiksi biasanya tercipta dari kehidupan sehari-hari dan fakta sosial yang ada. Sesuatu dianggap data jika kenyataan itu dianggap diberikan oleh alam kepada indera manusia. Alam tidak mungkin menipu jadi kalau sesuatu diberikan oleh alam kepada indera manusia pastilah hal tersebut ada (Kleden, 2004).

Fiksi serius bermaksud menyajikan pengalaman kemanusiaan melalui faktafakta,tema-tema dan sarana-sarana kesastraan. Memahami dan menikmati hal tersebut terkadang harus dilakukan melalui semacam analisis terhadap bagian dan relasinya satu sama lain. Karakter, alur dan latar merupakan cerita,elemen-elemen ini berfungsi sebagai catatan kejadian imajinatif dari sebuah cerita (Stanton, 2007).

Penciptaan naskah drama Lolo memiliki objek utama seorang wanita bernama Kencana yang mengalami ketertindasan dan banyak konflik kehidupan. Tokoh Kencana ini tercipta dari akumulasi hasil observasi dan wawancara dengan para mantan penari sintrendi empat desa di Kecamatan Taman Pemalang, yaitu Desa Cokrah, Kebantalan, Kramat dan Surajaya, yang aktif maupun sudah tidak aktif.
Fakta yang telah didapatkan nantinya akan diolah kembali menjadi bentuk naskah drama yang di dalamnya tersusun konflik hingga klimaks. Tokoh Kencana akan digambarkan tidak mampu menyuarakan impian dan keinginannya serta segala sesuatu yang ada padanya telah dikonstruksi. Sekolah, kehidupan sosial hingga pernikahan, semuanya seolah menjadi bukan hak miliknya lagi, sesuai objek penciptaan yang terfokus pada ketertindasan wanita, maka penulis merasa teori feminisme mampu menjadi landasan teori Penciptaan naskahdrama Lolo.

Feminisme sendiri dikenal sebagai bentuk perlawanan terhadap pembagian kerja di suatu dunia yang menetapkan kaum laki-laki sebagai yang berkuasa dalam ranah publik seperti dalam pekerjaan, olahraga, perang, pemerintahan sementara kaum perempuan hanya menjadi pekerja tanpa upah dirumah, dan memikul seluruh beban kehidupan keluarga (Watkin, 2007).

Pengertian diatas sejalan dengan pengertian bahwa secara psikologis, lakilaki lebih rasional, lebih aktif, lebih agresif.Wanita sebaliknya; lebih emosional, lebih pasif dan submisif.Melalui pendapat itu karenanya banyak orang percaya bahwa wanita sudah sewajarnya hidup di lingkungan rumah tangga. Tugas ini adalah tugas yang diberikan alam kepada mereka: melahirkan daan membesarkan anak-anak di dalam lingkungan rumah tangga, serta memasak dan memberi perhatian kepada suaminya. Pembagian kerja tersebut di anggap merupakan pembagian kerja yang diatur oleh alam karena itu orang cenderung menganggapnya sebagai sesuatu yang alamiah (Budiman, 1981).

Akibat pemikiran tersebut, perempuan selalu berada dalam posisi nomor dua, seringkali dianggap lemah dan sangat membutuhkan kekuatan laki-laki untuk menjaganya. Para wanita seringkali tidak mampu mengambil keputusan dalam 
kehidupannya sendiri. Hal-hal alamiah yang dianggap wajar dan seolah-olah bertujuan melindungi sisi wanita yang lemah, nyatanya malah menimbulkan batasan dan ketidakadilan sikap yang didapatkan oleh para wanita.

a recognition of an imbalance ofpower between the sexes, with woman in a subordinate role to men. A belief that woman condition is social constructed and therefore can be changed. An emphasis on female autonomy (Hannam, 2007).

(Pengakuan tentang ketidakseimbangan kekuatan antara dua jenis kelamin, dengan peranan wanita berada dibawah pria.Keyakinan bahwa kondisi wanita terbentuk secara sosial dan maka dari itu dapat diubah.Penekanan pada otonomi wanita.)

Selain teori Feminisme yang telah dikemukakan diatas, tokoh Kencana di dalam naskah drama Loloakan mengalami perubahan sikap dalam kehidupan sosialnya.Perubahan sikap Kencana bukan hanya berasal dari faktor internal diri melainkan juga dipengaruhi oleh keadaan lingkungan sekitarnya yang terus mempengaruhi kepribadian Kencana. Tekanan yang diberikan dari lingkungan sosialnya membuat alam bawah sadar Kencana melakukan pembelaan tidak langsung terhadap dirinya sendiri dengan melakukan perubaan sikap dan perilaku.

Sikap tidak dibawa sejak individu dilahirkan, namun terbentuk dalam perkembangan individu yang bersangkutan, sikap sendiri merupakan masalah yang penting dan menarik dalam lapangan psikologi, khususnya psikologi sosial.Pendapat tersebut sekiranya cukup beralasan bila dilihat dari segi pentingnya masalah sikap dikaitkan dengan perilaku atau perbuatan manusia dalam kehidupan sehari-hari. Sikap yang ada pada seseorang akan memberikan warna atau corak pada perilaku atau perbuatan orang yang bersangkutan.

Sesuai dengan uraian tersebut, maka teori tingkah laku sosial dirasa tepat untuk digunakan.Tingkah laku seseorang atau aktivitas yang ada pada inividu atau organisme itu tidak timbul dengan sendirinya, tetapi sebagai akibat dari stimulus yang diterima oleh organisme yang bersangkutan baik stimulus eksternal maupun stimulus internal. Tingkah laku seseorang sebagai respon terhadap keadaan di sekitarnya yang menimbulkan perilakuperilaku dan menyesuaikannya dengan apa yang dialaminya (Bimo, 2003).

Ide cerita yang berasal dari kehidupan nyata para penari sintren Pemalang menjadi sebuah pengalaman empirik yang kemudian penulis coba ubah ke dalam pengalaman imajinatif dengan menggunakan teori transformasi dalam penciptaan naskah dramanya. Hasil temuan penulis di lapangan tidak serta merta mampu diubah begitu saja ke dalam bentuk naskah. Potongan pengalaman empirik tersebut kemudian ditransformasi menjadi struktur yang utuh dan bermakna.

Sesuai dengan teori diatas, maka pengalaman yang sudah didapatkan di lapangan berupa data kemudian menjadi ide dasar dalam pembuatan sinopsis, treatment, dan naskah drama Lolo dengan menambahkan sentuhan imajinatif dalam alur cerita. Pengalaman empirik yang ditemukan, kemudian diubah kedalam bentuk sinopsis, treatment dan naskah drama itu merupakan bentuk transformasi, sesuai dengan teori yang digunakan.

\section{Metode Penelitian dan Penciptaan}

Metode adalah cara yang telah diatur dan dipikirkan secara baik-baik untuk mencapai sesuatu maksud dalam ilmu pengetahuan dan sebagai cara untuk memudahkan kreator mengarahkan jalur gagasan untuk menjadi sebuah naskah 
drama panggung. Metode penciptaan adalah bagaimana proses yang dipergunakan dalam menciptakan sebuah naskah drama berjudul Lolo. Naskah drama Lolo berasal dari kehidupan penari Sintren Pemalang. Sebelum menuju tahapan proses kreatif untuk menciptakan naskah drama, maka perlukan pengumpulan sumber data dari beberapa pihak yang bersangkutan langsung.

Studi pustaka merupakan teknik pengumpulan data dengan jalan mengumpulkan, mempelajari dan meneliti data - data yang diperoleh dari beberapa sumber, makalah maupun buku. Hal ini dikarenakan informasi mengenai kesenian sintren memiliki banyak versi.

Metode wawancara atau interview merupakan teknik pengumpulan data melalui proses tanya jawab dengan narasumber secara lisan. Lewat teknik wawancara diharapakan sumber penelitian semakin Lengkap.

Metode penyebaran kuisioner menjadi salah satu metode dalam pengumpulan data. Penyebaran kuisioner dilakukan kepada masyarakat umum, beberapa praktisi pendidikan dan siswasiswi kelas XII Bahasa SMA N 2 Pemalang

Metode pengamatan (observasi) merupakan teknik dengan cara melakukan pengamatan secara langsung pada objek yang diteliti. Pada metode ini peneliti terjun langsung mendatangi lokasi tujuan observasi. Tahap observasi kali ini dilakukan di beberapa desa di dua kecamatan di daerah Pemalang Provinsi Jawa Tengah. Melalui pengamatan secara langsung, data-data penelitian yang didapatkan diyakini mampu memiliki tingkat akurasi yang tinggi.

Hasil studi pustaka, wawancara (interview), menyebar kuisioner dan pengamatan (observasi) akan dipadukan pada tahap pengolahan data. Data yang terkumpul akan dianalisis secara kualitatif (berdasarkan data itu sendiri) tanpa menggunakan statistik. Pengolahan data diarahkan pada objek penelitian, yakni kehidupan penari sintren sebagai bahan penciptaan naskah drama setelah kreator melakukan tahap proses penelitian.

\section{Unsur-unsur Drama}

1. Premise

Premise merupakan rumusan intisari cerita sebagai landasan idiil dalam menentukan arah tujuan cerita (Harymawan, 1986). Lajos Egri menyatakan bahwa segala sesuatu pasti mempunyai maksud dan tujuan atau disebut premise (Egri, 1960). Berawal dari permasalahan eksistensi dan kemunafikan yang sering terjadi di kehidupan manusia, penulis kemudian mengolahnya menjadi tolak ukur dari penemuan premise. Eksistensi demi mendapat citra yang baik dan memuaskan keinginan publik seolah menjadi hal wajar dalam kehidupan masyarakat masa kini.

Hal semacam itu tercermin pula dalam masyarakat yang terdapat kebudayaan sintren didalamnya.sintren memang identik dengan tarian dan wanita cantik, namun sintren masa kini telah mengalami perubahan bentuk, yaitu menjadi lebih terbuka dengan musik dangdut dan saweran. Penelitian dan observasi lapangan yang dilakukan menghasilkan temuan bahwa grup sintren daerah Pemalang di era modern ini telah melakukan berbagai perubahan dalam bentuk pertunjukan karena mengikuti keinginan masyarakat penonton. Perubahan pola tarian, musik iringan menjadi dangdut dilakukan untuk menarik animo pentonton. Di lain sisi, masyarakat penonton seringkali merasa perlu mengkritisi perubahan tersebut tanpa sadar bahwa mereka juga yang sebenarnya telah melakukan perubahan tersebut, lantas menjadikan penari sintren sebagai objek yang dapat di jadikan tolak ukur kesalahan.

2. Plot atau Alur 
Alur adalah rangkaian peristiwa yang satu sama lain dihubungkan dengan hukum sebab akibat (Sumardjo, 1994). Alur merupakan salah satu aspek penting dalam drama karena alur merupakan pembentuk kerangka cerita. Aristoteles menyatakan bahwa alur adalah roh drama (Sumardjo, 1994). Naskah drama Lolo memiliki alur bolak-balik. Peristiwa yang dikisahkan tidak harus berurutan dan mengikuti waktu. Peristiwa yang merupakan akibat dari peristiwa-peristiwa sebelumnya, justru dikisahkan terlebih dahulu daripada peristiwa sebelumnya yang menjadi penyebab munculnya peristiwa akibat (Nurgiyantoro, 1994). Menurut Jacob Sumardjo dan Saini K.M unsur-unsur alur drama ada tiga, yaitu:

a. Unsur Ketegangan (Suspense)

Ketidakpastian yang berkepanjangan dan semakin menjadi-jadi tentunya akan menimbulkan ketegangan. Adanya ketegangan dalam drama menumbuhkan dan memelihara rasa ingin tahu penonton dari awal sampai akhir suatu cerita.Unsur ketegangan dalam naskah drama Lolo terdapat ketika Kencana dilarang bersekolah oleh $\mathrm{Bu}$ Marti hingga menimbulkan perdebatan dan terkuaklah rahasia tentang Pak Joko yang selama ini di simpan rapatrapat oleh ibunya.

b. Unsur Dadakan (Surprise)

Unsur dadakan akan menyusun cerita sedemikian rupa hingga muncul dugaandugaan yang tidak disangka-sangka oleh pembaca dan menganggetkan. Unsur ketegangan dalam naskah drama Lolo tampak pada adegan ketika Kencana tibatiba diserbu oleh laskar ibu-ibu yang cemburu terhadapnya. Wajah dan tubuhnya habis diserbu oleh laskar ibu-ibu, hingga akhirnya dia tiba-tiba diminta untuk menikah dengan seorang lelaki desa yang baru kembali dari kota. Unsur dadakan dihadirkan oleh penulis untuk tetap menjaga antusiasme pembaca dan penonton dalam mengikuti jalannya cerita.Selain itu unsur dadakan tentunya diperlukan dalam setiap penciptaan sebuah naskah drama.

c. Unsur Ironi Dramatik

Unsur ironi dramatik membentuk pernyataan-pernyataan atau perbuatanperbuatan tokoh cerita yang seakan-akan meramalkan apa yang akan terjadi (Sumardjo, 1994). Unsur ironi dramatik ini di susun atas unsur dadakan dan unsur ketegangan. Unsur ironi seolah-olah menjadi puncak dari jalannya cerita, didalamnya tersusun unsur dadakan dan ketegangan yang kemudian membuat pembaca maupun penonton mampu tergugah. Unsur ironi terjadi ketika Kencana menyaksikan perbuatan persetubuhan antara suaminya Landung dengan Juna yang notabene ia kenal sebagai sepasang sahabat dan patner kerja. Kencana yang terus dipengaruhi Suara Gaib akhirnya melakukan pembunuhan terhadap Landung dan Juna.

\section{Penokohan atau Perwatakan}

\section{Tokoh Kencana}

Kencana adalah seorang anak gadis dari $\mathrm{Bu}$ Marti dan Pak Joko. Kencana diceritakan baru saja menyelesaikan pendidikan SMP nya, Kencana merupakan tokoh utama dalam naskah drama Lolo. Ia menjadi penggerak dalam jalannya cerita. Secara Fisiologis, Kencana digambarkan sebagai gadis berusia 14 tahun, berambut pendek diatas bahu memiliki wajah sayu dan berkulit putih. Badannya tidak terlalu tinggi, tetapi tidak juga pendek. Badannya kurus dan buah dadanya tidak besar, karena menggambarkan usianya yang masih remaja. Secara sosiologis ia memiliki keadaan yang sama dengan kedua orang tuanya. Berasal dari keluarga berstatus menengah kebawah.Hanya yang membedakan, Kencana sempat menyelesaikan jenjang pendidikan SMP. Dimensi Psikologi Kencana adalah gadis yang ceria namun sebenarnya ia menyimpan 
luka yang dalam. Ia dibesarkan dalam keluarga yang timpang, ibunya yang selalu menekan dan bapaknya yang selalu kalah dengan keadaan. Menimbulkan sikap kebimbangan dalam diri kencana

2. Tokoh Pak Joko

Pak Joko merupakan suami dari $\mathrm{Bu}$ Marti dan ayah dari Kencana.Tokoh Pak Joko termasuk sebagai tokoh pembantu utama. Secara Fisiologi Pak Joko adalah seorang laki-laki berusia 50 tahun, berkumis tipis, berambut panjang sebahu yang hitam dengan sedikit uban, berbadan tinggi dan tegap meski usia nya sudah cukup tua, dia tidak bisa dikatakan rupawan, tetapi juga tidak begitu buruk. Secara Sosiologis Pak Joko berasal dari kalangan menengah kebawah, ia tinggal disebuah rumah gubuk yang sudah tidak layak huni. Pekerjaan sehari-harinya adalah sebagai seorang penjual kayu bakar.Kekurangan ekonomi ini membuat Kencana, anaknya tidak mampu meneruskan pendidikannya ke jenjang yang lebih tinggi dan terpaksa hanya mampu lulus SMP kemudian melanjutkan bekerja sebagai penari sintren. Kurangnya ekonomi seringkali menimbulkan pertengkaran dengan sang istri. Secara psikologis Pak Joko digambarkan sebagai sosok yang baik hati, penyabar dan penyayang serta mendukung keinginan anaknya Kencana.Ia juga tergambar sebagai seorang yang bijaksana, senang memberikan nasehat serta pesan kepada Kencana. Disatu sisi, tokoh Pak Joko selalu berbenturan visi misi dengan istrinya yang keras.Selain itu, Pak Joko memiliki sebuah penyakit mental.

\section{Tokoh Bu Marti}

$\mathrm{Bu}$ Marti adalah istri dari Pak Joko dan merupakan ibu dari Kencana.Tokoh $\mathrm{Bu}$ Marti merupakan tokoh pembantu utama dan banyak bersinggungan dengan tokoh utama.Ia merupakan salah satu tokoh yang berperan besar dalam jalannya cerita. Ia hidup dan tinggal bersama dengan Pak Joko sejak kecil, karena orangtua Bu Marti yang telah menemukan Joko kecil dan merawatnya dengan senang hati. Sejak kanak-kanak Bu Marti dan Pak Joko sering bermain bersama. Secara Fisiologis Tokoh $\mathrm{Bu}$ Marti digambarkan sebagai seorang wanita berusia 48 tahun, berkulit kuning langsat dengan rambut ikal sebahu yang biasanya ia ikat. Berbadan pendek namun tidak bungkuk, tidak kurus tetapi juga tidak gemuk. Secara Sosiologis, $\mathrm{Bu}$ Marti digambarkan berada dalam taraf menengah kebawah, ia bekerja serabutan dan tidak sempat bersekolah tinggi. Tokoh $\mathrm{Bu}$ Marti dan Pak Joko memiliki kesamaan kelas.Berasal dari kalangan menengah kebawah yang serba kekurangan, kekurangan ekonomi tersebut dibuktikan dengan visualisasi rumah mereka yang reyot dan hanya menggunakan bambu.Secara Psikologis Bu Marti adalah seorang wanita yang senang mendominasi, berwatak keras, matrealistis dan dalam berucap selalu tajam.

4. Tokoh Landung

Landung adalah tokoh yang nantinya akan menjadi suami dari Kencana. Landung sebelumnya digambarkan sebagai anak desa yang ikut orangtuanya merantau kekota dan baru kembali pada saat Kencana menjadi sintren.Secara fisiologi Landung adalah seorang laki-laki berusia 28-29 tahun dan berambut cepak. Ia memiliki kulit sawo matang, tubuhnya tidak terlalu kurus atau pun gemuk. Landung yang lama tinggal di kota dan bekerja di kantoran terbiasa menggunakan pakaian rapi seperti kemeja. Pembawaannya halus, tertata dan dalam perkataannya menyiratkankesombongan. Secara sosiologi Landung berasal dari kalangan menengah ke atas, pada usia 5 tahun ia pindah ke kota. Landung digambarkan pernah kuliah kemudian bekerja di perusahaan besar, di kota. Setelah kembali ke desa asalnya, Landung juga menjadi orang yang memiliki pengaruh karena merupakan orang kaya.Secara psikologi Landung adalah orang yang 
ambisius, ingin dipandang dan selalu ingin menjadi yang nomer satu.Landung termasuk orang yang mudah mengambil keputusan, sangat modern dan cukup berwawasan luas. Meski pada pengaplikasiannya ia merupakan orang yang tergolong sombong. Namun, kesombongan dan ambisinya mampu ditutupi dengan pembawaannya yang tenang.

\section{Tokoh Juna}

Juna adalah teman dari Landung, mereka bertemu ketika Landung pindah dan bekerja di kota. Juna kemudian memilih ikut Landung yang pulang kembali ke desanya.Dia berencana memudahkan pekerjaan Landung di desa dengan membantu menanamkan modal.Secara fisiologi Juna adalah lelaki berusia 27 tahun, berkulit kuning langsat, bertubuh kurus dan juga senang menggunakan pakaian rapi bahkan syal.Bahasa tubuhnya seringkali menyerupai perempuan.Secara sosiologi Juna berasal dari kalangan menengah ke atas, bahkan bisa di katakan Juna memiliki kedudukan diatas Landung.Juna bahkan yang membantu pekerjaan Landung ketika pindah ke desanya.Secara psikologi Juna adalah orang yang juga memilki ambisi besar, sombong, senang mengatur dan diamdiam memiliki rasa suka kepada Landung.

6. Tokoh Mbah Darmo

Mbah Darmo merupakan dukun sintren yang membantu pekerjaan Kencana.Tokoh Mbah Darmo merupakan tokoh pembantu dalam jalannya cerita.Secara fisiologis, Mbah Darmo merupakan lelaki berusia 60 tahun, bertubuh kurus, berambut cepak dan senang menutupi kepalanya dengan kain, berkulit coklat dengan tatapan matanya yang sayu dan cara bicara yang halus. Secara sosiologis, Mbah.Darmo berada dikalangan menengah keatas.Ia lumayan memiliki harta kekayaan dan kedudukan di desanya. Karena ia merupakan pemilik grup sintren tempat Kencana, Rainah dan Paijo bekerja. Secara psikologis, Mbah Darmo adalah orang yang spititualis, bijaksana dan selalu mempercayai hal-hal magis.

7. Tokoh Rainah

Rainah adalah teman Paijo dalam grup sintren yang digawangi Mbah Darmo.Tokoh Rainah merupakan tokoh pembantu dalam jalannya cerita.Secara fisiologis Rainah merupakan wanita berusia 30 tahun, berambut hitam sebahu dan agak ikal, dalam kesehariannya ia senang mengikat rambutnya. Warna kulitnya coklat dan badannya terlalu tinggi serta memiliki badan yang cukup berisi. Secara sosiologis, Rainah tergolong berada dikalangan menengah kebawah karena ia juga bekerja serabutan. Selain itu Rainah juga termasuk orang yang matrealistis dan senang mengaitkan segalanya dengan uang. Secara psikologis Rainah, termasuk orang yang penurut dan pandai bergaul meski dalam percakapan ia sering kurang tanggap.

8. Tokoh Paijo

Paijo adalah pembantu Mbah Darmo dalam grup sintren dimana Kencana menjadi primadonanya.Tokoh Paijo merupakan tokoh pembantu dalam jalannya cerita. Secara fisiologis, Paijo digambarkan sebagai lelaki berusia 35 tahun dimana perawakan tubuhnya tidak terlalu tinggi, badannya kurus, berkulit hitam dan selalu menggunakan baju berwarna terang yang sebenarnya tidak cocok dengan warna kulitnya yang hitam. Secara sosiologis, ia termasuk kategori menengah kebawah karena bekerja serabutan. Tetapi meski berasal dari kalangan menengah kebawah, Paijo bisa dikategorikan sebagai seseorang yang pandai mengikuti perkembangan zaman.Secara psikologis, Paijo adalah termasuk orang yang supel, pandai bergaul dan senang terhadap kemajuan teknologi. Meski beberapa kali ia senang menyombongkan diri.

9. Tokoh Laskar Ibu-ibu 
Laskar ibu-ibu terdiri dari Ibu 1, Ibu 2 dan Ibu 3 yang merupakan tokoh pembantu dan kehadirannya selalu bersamasama. Tidak ada dimensi tokoh yang khusus pada tokoh ini, laskar ibu-ibu ini terdiri dari wanita berusia 30-38 tahunan dan hanya bekerja sebagai ibu rumah tangga yang mengurusi suaminya.Merasa eksistesinya terganggu dengan kehadiran Kencana yang mampu membuat gandrung para lelakinya, kemudian menjadikan laskar ibu-ibu ini menyerang Kencana.

10. Tokoh Bapak-bapak

Para warga terdiri dari tokoh Warga 1, Warga 2 dan Warga 3. Sejalan dengan penokohan para ibu, tokoh para warga nantinya akan diisi oleh banyak lelaki yang digambarkan berusia 34-40 tahun dengan perawakan berbeda-beda, tidak ada spesifikasi khusus dalam dimensi tokoh para warga. Tokoh ini merupakan visualisasi para lelaki yang gandrung terhadap sintren Kencana.

\section{Tokoh Suara Gaib}

Tokoh suara gaib sebenarnya merupakan tokoh rekaan yang lahir dari fikiran dan hati tokoh Kencana sendiri.Tokoh ini seolah-olah menjadi hantu yang sering datang menganggu Kencana. Pada klimaks cerita, tokoh suara gaib akan hadir dan mempengaruhi Kencana untuk melakukan aksi pembunuhan terhadap Landung dan Juna.

\section{Latar atau Setting}

Latar adalah lingkungan yang melingkupi sebuah peristiwa dalam cerita, semesta yang berinteraksi dengan peristiwaperistiwa yang berlangsung.Naskah drama Lolo memiliki latar cerita yang terbagi dalam beberapa bagian, hal itu ditujukan untuk mendukung jalannya alur peristiwa.

1. Latar Waktu

Latar waktu dalam naskah drama Loloterbagi dalam tiga bagian yaitu padapagi, sore serta malam hari.Hal ini disusun berdasarkan imajinasi dan kebutuhan penulis dalam upayanya untuk mempertahankan alur dalam cerita agar konflik tetap terjaga.

2. Latar Tempat

a. Rumah Kencana

Salah satu tempat berlangsungnya peristiwa dalam naskah drama Lolo adalah rumah Kencana. Rumah ini dihuni olehh Kencana, $\mathrm{Bu}$ Marti dan Pak Joko.Kemiskinan dan ketertindasan yang menjadi salah satu permasalahan didalam naskah nantinya dapat tervisualkan melalui gambaran rumah reyot milik keluarga Kencana.

b. Rumah Landung

Setelah menikah, Kencana pindah ke rumah Landung yang digambarkan jauh lebih layak dari rumah keluarga Kencana. Rumah Landung masih berada disatu desa yang sama dengan rumah Kencana. Rumah Landung ini nantinya akan menjadi visual pendukung untuk menunjukan kekuasaan materi yang Landung miliki. Sebuah rumah modern yang memiliki tatanan perabotan rapi.

c. Halaman Kosong

Latar tempat lain yang menjadi tempat jalannya cerita adalah sebuah halaman kosong. Halaman kosong disebuah sisi desa ini nantinya menjadi tempat dimana Kencana dan grup sintrennya akan melakukan pertunjukan sintren. Seperti yang diketahui, bahwa pementasan sintren biasanya dilaksanakan disebuah halaman kosong yang luas.

3. Latar Suasana

Naskah drama Lolo di dalamnya terdapat berbagai suasana yang muncul dalam setiap adegan yang ditulis.Suasana tersebut berupa suasana tegang dimana ditunjukan ketika adegan Kencana berselisih paham dengan $\mathrm{Bu}$ Marti dan Pak Joko mengenai keinginannya bersekolah yang ditentang oleh $\mathrm{Bu}$ Marti. Ada pula suasana kesedihan, ditujukan saat Kencana harus 
putus sekolah kemudian dipaksa menikah. Selain itu, naskah drama Lolo memiliki suasana bahagia ketika para warga asyik menyawer sintrendan suasana tragis dalam alur cerita ketika Kencana akhirnya harus melihat kegiatan persetubuhan yang dilakukan suaminya dengan teman kerjanya sendiri.Salah satu suasana dalam naskah Lolo dimana Kencana melihat adegan persetubuhan suaminya yang membuatnya terguncang hebat.

\section{Dialog}

Dialog merupakan sarana primer dalam sebuah drama. Dialog didalam drama merupakan situasi bahan utama. Luxsemburg, dan kawan-kawan menyebutkan bahwa dialog-dialog didalam drama merupakan bagian terpenting dalam sebuah drama, sampai taraf tertentu ini juga berlaku bagi monolog-monolog. Dialog dalam naskah drama Lolo dilakukan oleh tokoh satu, dua tiga dan seterusnya. Munculnya dialog dalam naskah drama Lolo sebagai media ungkap keadaan dan situasi yang ada. Dalam naskah drama Lolo dialog memiliki peran penting sebagai penyampai pesan dan petunjuk jalannya peristiwa. Dialog juga menjadi penanda keberadaan tokoh dalam jalannya alur cerita. Adapun contoh salah satu dialog dalam sebuah adegan sebagai berikut:

01. LANDUNG: (Memeluk Juna erat) Tak apa, aku senang kamu

kembali sayang (Membelai wajah Juna)

02. JUNA: Istrimu ada dimana?

03. LANDUNG : Tidak usah pikirkan dia, dia kusuruh menginap

dirumah orangtuanya. Kini kita tinggal berdua saja, kita bisa berbagi kasih seperti biasanya.

04. JUNA :(Mencubit perut Landung) Kamu pandai menggoda!

(Landung perlahan menuntun Juna masuk ke dalam kamar. Didalam kamar, mereka segera saling berbagi hasrat. Namun tanpa diketahui oleh Landung dan Juna, Kencana tiba-tiba kembali dari rumah orangtuanya, ia lantas begitu kaget melihat apa yang dilakukan suaminya dengan Juna.

05. SUARA GAIB: (Tertawa makin keras) Hihihihihihihihiihi. Tak ada manusia jahat, manusia hanya terlalu bodoh untuk memahami bahwa dirinya picik. Membohongi diri agar meyakini kebaikan sendiri! Dan yang paling terbodoh adalah yang berhasil ditipu. Sepertimu dan aku... Hihihihi.....

06. KENCANA: (Matanya menera-wang kosong, seperti tak percaya terhadap apa yang baru saja diketahuinya) Apakah manusia memang selalu jahat dan penuh kepentingan? Penuh tuntutan yang tak ada habisnya?

DARI DALAM KAMAR LANDUNG DAN JUNA SEMAKIN MESRA BERBAGI HASRAT, HUBUNGAN PERCINTAAN ITU TERGAMBAR MELALUI TARIAN EROTIS YANG MEREKA LAKUKAN. KENCANA SEMAKIN TERPAKU MENYAKSIKAN SEMUA YANG TERJADI. BERSAMA MEMANASNYA ADEGAN PERCINTAAN JUNA DAN LANDUNG, LURUHLAH AIR MATA KENCANA. TIBA-TIBA SUARA GAIB KEMBALI MUNCUL, MENYERUKAN KALIMAT-KALIMAT YANG MEMBUAT KENCANA SEMAKIN KACAU.

07. SUARA GAIB: Saksikanlah! Nikmati dan reguklah kemurkaan!

Menyatulah pada dosa! Luruhlah pada arwah paling keparat! Tuntaskan dendammu! Kencana!! (Kencana terisak hebat) Bodoh! Hentikan air mata itu! Tidak ada yang pernah benar-benar mendengarkan dan memahamimuu! Apa kau tidak lelah berpura-pura menerima segalanya? Apa kau akan selalu akan jadi bodoh sampai kematianmu? Seperti aku? Hihihihiii...

Salah satu dialog atau percakapan yang diucapkan tokoh Landung kepada Juna menerangkan mengenai status hubungan diantara keduanya, dialog antar keduanya 
juga menerangkan bagaimana kondisi mereka yang tetap melakukan sebuah jalinan kasih meskipun Landung sudah menikah dengan Kencana. Hingga akhirnya tokoh Kencana dengan bujukan suara gaib akhirnya melakukan pembunuhan terhadap Landung dan Juna.

\section{Simpulan}

Naskah drama Lolo lahir setelah melalui sebuah proses yang panjang, mulai dari melakukan observasi, mengumpulkan data, merangkai seluruh imajinasi, melakukan penciptaan naskah drama yang utuh hingga menyusun karya ilmiah. Ketertarikan pada bentuk kesenian sintren Pemalang dan realitas kehidupan para wanita penari sintren menjadi dasar penciptaan naskah drama Lolo.

Pergeseran bentuk tarian pementasan grup-grup sintren masa kini di hampir seluruh Kecamatan di Kabupaten Pemalang menjadi lebih erotis, kostum para penari lebih terbuka, serta berubahnya musik iringan sintren menjadi menggunakan musik dangdut hingga menimbulkan banyak stigma negative pada masyarakat Pemalang yang memandang miring terhadap kesenian Sintren masa kini.

Fakta yang didapat melalui beberapa narasumber telah melalui proses perumpaan, penafsiran baru untuk memenuhi kebutuhan penulis dalam menciptakan naskah drama. Penyampaian dengan gaya modern serta permasalahan-permasalahan masa kini yang diangkat tidak mengkesampingkan nilai tradisi yang ada. Proses penciptaan naskah drama Lolo tidak bermaksud sepenuhnya menggurui dan memberikan pembenaran terhadap situasi kehidupan sintren Pemalang, namun sebagai upaya kritis terhadap isu yang ada.

\section{Daftar Pustaka}

Bimo, W. (2003). Psikologi Sosial. Yogyakarta: Penerbit Andi.

Budiman, A. (1981). Pembagian Kerja Secara Seksual. Jakarta: PT. Gramedia.

Egri, L. (1960). The Art of Dramatic Writing. New York: Simon \& Schuster, inc.

Hannam, J. (2007). Feminism, London: Pearson/Longman.

Harymawan, RMA. (1986). Dramaturgi. Bandung: Remaja Rosdakarya.

Kleden, I. (2004). Sastra Indonesia Dalam Enam Pertanyaan Esai-esai Sastra dan Budaya. Jakarta: Grafitti dan Freedom Institute.

Lubis. (1984). Teknik Mengarang, Cerita ke-1 Mochtar Lubis. Jakarta: P.T. Nunung Jaya.

Nurgiyantoro, B. (1994). Teori Pengkajian Fiksi. Yogyakarta: Gadjah Mada University Press.

Sahid, N. (2008). Sosiologi Teater, Yogyakarta: Prasista.

Stanton, R. (2007). An Introduction to Fiction. Yogyakarta: Pustaka Pelajar.

Sumardjo, J. (1994). Apresiasi Kesusastraan. Jakarta: Gramedia.

Triratnawati, A. (2012). Revitalisasi Sintren di Kota dan Kabupaten Pekalongan. Yogyakarta: Gadjah Mada University Press.

Watkin. (2007). Feminisme untuk pemula, Yogyakarta: Resist Book. 